\title{
Corrected synonymies: the identities of Strymon bicolor (Philippi, 1859) and Strymon heodes (Druce, 1909) (Lepidoptera: Lycaenidae)
}

\author{
Zs. BÁLINT ${ }^{1} \&$ D. BENYAMINI ${ }^{2}$ \\ ${ }^{1}$ Zsolt Bálint, Hungarian Natural History Museum, Department of Zoology,H-1088 Budapest, Baross utca \\ 13, Hungary.E-mail: balint.zsolt@nhmus.hu \\ ${ }^{2}$ Dubi Benyamini, 4D MicroRobotics, 91 Levona Street, Bet Arye, 7194700, Israel. E-mail: \\ dubi_ben@netvision.net.il
}

\begin{abstract}
The South American hairstreak species Strymon bicolor (Philippi, 1859) and S. heodes (Druce, 1909) are diagnosed and their synonymies are revised. The distribution of $S$. bicolor is restricted to the Andean-Patagonian region south of the Atacama Desert and represented now in Argentina and Chile by seven available species group names, considered as subjective synonyms. However, some of these names can most probably be considered as valid taxa. A key to identification is given for distinguishing the superficially most similar Strymon species patterned by orange scaling in the dorsal wing surfaces. It is noted that the Austral S. bicolor group and the Central Peruvian S. heodes appear to belong to a mimicry ring inhabiting the dry areas of the Andes.
\end{abstract}

Keywords. Argentina, Chile, Peru, characters, Eumaeini, Strymon, Eiseliana, Heoda, bicolor, heodes, mimicry.

\section{INTRODUCTION}

$\mathrm{T}$ he nominal species Lycaena bicolor was described on the basis of an unstated number of male and female specimens originating from the vicinity of Santiago de Chile, Chile (Philippi 1859). No type material is known to be extant. The genus Eiseliana was erected by Ajmat de Toledo (1978) based on the type species Eiseliana koehleri, described as new. The genus was reviewed by Johnson et al. (1992) transferring several taxa to Eiseliana from various genera, including Lycaena bicolor, as a widely distributed hairstreak in Chile and placed in its synonymy two names established subsequent to Philippi.

In the above mentioned paper Johnson and his co-authors also erected the genus Heoda based on Thecla heodes Druce, 1909 as type species. The nominal species Thecla heodes was described by Druce (1909) on the basis of at least two syntype specimens collected in „Uramarca" [= Yuracmarca] (one putative male) and "San Marcas" [= San
Marcos] (one female), both allegedly located in department Ancash, Peru. The putative male syntype (which is actually a female) was designated as lectotype by Johnson et al. (1992), and this specimen was illustrated in colour by D'Abrera (1995: 1259, as „E. heodes ? \& R”). Later the genus was reviewed by Benyamini \& Johnson (1996) describing Heoda erani as new and listing $H$. atacama Johnson \& Miller, 1992, H. nivea Johnson, Miller \& Herrera, 1992, H. shapiroi Johnson, Miller \& Herrera, 1992, H. suprema Johnson, Miller \& Herrera, 1992 and $H$. wagenknechti (Ureta, 1947) as congeners.

The generic names Eiseliana and Heodes were combined with several species-group names in the subsequent literature ( $c f$. Bridges 1994, Peña \& Ugarte 1997). Robbins \& Nicolay (2002) presented a new concept of the genus Strymon Hübner, 1818; they considered Eiseliana and Heodes as junior subjective synonyms of Strymon. Moreover, Thecla heodes was placed in the synonymy of Strymon bicolor with further 
seven species-group names in the Strymon istapa group, but without any remarks. Making the situation more complicated Robbins (2004) listed Strymon heodes as a valid species, again without any note, but indicating five species-group names originally combined with the generic names Eiseliana, Heoda and Thecla as junior subjective synonyms. Beside this action Strymon bicolor was kept as a valid species having just two synonyms, reflecting the work of Johnson et al. (1992).

The species Strymon bicolor with dorsally orange coloured wing surfaces and its look-alike species are widely distributed in the Andes from central Peru south to the Patagonian Andes of Argentina and Chile. The Peruvian Strymon heodes is the most northerly taxon and is one of the most poorly known Strymon, because modern published faunistic data are non-existent and in museum collections specimens are rare. Orange Strymon hairstreaks are far better represented in both sides of the Andes south of the Atacama region and display wide phenotypical variability, many of them having been treated as valid species (Peña \& Ugarte 1997) but synonymized by Robbins (2004).

For a revision of the Chilean fauna (Benyamini et al. in prep.) it is crucial to understand this diversity. Therefore, in this paper we address the following issues (1) what is the taxonomic identity of $S$. heodes ?; (2) what is the taxonomic identity of S. bicolor ?; (3) present an identifycation key to the most similar orange species placed in the Strymon istapa group of Robbins \& Nicolay (2002); (4) correct the synonymic list of $S$. bicolor; and (5) discuss some aspects regarding these species.

\section{MATERIALS AND METHODS}

125 male and 89 female specimens of the Strymon bicolor complex from Chile $(\mathrm{n}=163)$ and Argentina $(\mathrm{n}=51)$ have been examined. From Peru (department Ancash) altogether 19 specimens of $S$. heodes (ten males and nine females) were studied. These specimens are deposited in the collection of Dubi Benyamini (Bet Aryre, Israel), in the Hungarian Natural History Museum (HNHM; Budapest, Hungary), in the Museo de Historia Natural, Universidad Nacional Mayor de San Marcos (MUSM; Lima, Peru), and in the Natural History Museum (NHMUK; London, UK) and in the Smithsonian Institution National Museum of Natural History collection (SINMNH; Washington D.C., USA).

The genitalia of 26 specimens have been dissected (S. bicolor: 7 males, 16 females; S. heodes: 2 males, 1 female) databased and digitized in the HNHM following the serial numbers of Zsolt Bálint. Abdomens were dissected using standard techniques, and the preparations are kept with the relevant specimens in plastic microvials filled with glycerin.

References for the two taxa discussed are given, also indicating the supplementing figures, when they are extant.

\section{RESULTS}

\section{Key to the orange species of the Strymon istapa group}

1. Dorsal wing-surfaces are generally brown or black in both sexes forewing ventral surface limbal area white, grey or brown ..................................... Strymon (various species of the genus-group)

Dorsal wing-surfaces are with more or less extended orange colouration in both sexes, forewing ventral surface limbal area orange (S. bicolor group) ..... 2

2. Dorsal hindwing surface entirely orange coloured in both sexes, hindwing with tail .........S. wagenknechti Dorsal hindwing surface limbal area orange coloured otherwise brown in both sexes, hindwing without tail (S. bicolor and $S$. heodes) ...................... 3

3. Dorsal wing-surface basal areas in both sexes with gleaming scales, hindwing submargin with light scaling ...................................................... S. heodes

Dorsal wing-surface basal areas in both sexes without gleaming scales, hindwing margin without light scaling. S. bicolor 


\section{Identity of Strymon heodes}

(Figures 1-5, 10,)

Thecla heodes Druce, 1909: 437, pl. 11, figs 10-11; Draudt 1920: 810, pl. 145, row k, figs. "heodas [sic]"

Eiseliana heodes (Druce): Bridges 1988: II.33; D’Abrera 1995: 1244, 1259, figs. „E. heodes $\widehat{~} \mathrm{R}$ ”, “E. heodes $+\mathrm{V}, "$ [paralectotype], "E. heodes ? \& R." [lectotype].

Heoda heodes (Druce): Johnson et al. 1992: 129 (p. 130: lectotype designation), figs. 11AB (lectotype), 14.

Strymon heodes (Druce): Robbins \& Nicolay 2002: 90 (in synonymy of Strymon bicolor); Robbins 2004: 131.

The original type series of Thecla heodes consisted of at least two syntypes, which Druce regarded as a male (his fig. 10), from "Uramarca", and a female (his fig. 11) from "San Marcas [sic]". Druce also remarked that his "male" lacked a FW scent pad (p. 438: "differs from T. quadricmaculata Hew. and its allies by the male wanting the prominent patch of dark scales at the end of the cell of the fore-wing"), which means he was actually dealing with a female.

The localities of the syntype specimens are in need of clarifications. "Uramarca" is almost without doubt Yuracmarca, located in Ancash at $08^{\circ}$ $46^{\prime} \mathrm{S}, 77^{\circ} 54^{\prime} \mathrm{W}, 1,450 \mathrm{~m}$, a locality visited by Simons in December 1899; "San Marcas" or "San Marco" should be a locality (San Marcos) in Cajamarca (at $07^{\circ} 20^{\prime} \mathrm{S}, 78^{\circ} 10^{\prime} \mathrm{W}, 2245 \mathrm{~m}$ ) that Simons visited in November 1899 (cf. Lamas 1976) (see Fig. 11).

Johnson et al. (1992) designated as lectotype the female specimen of Druce (their figs. 11A-B), which they said was from "San Marcas". But that specimen (in NHMUK) bears now the labels "Uramarca" and "Type $O$ " " and matches precisely Druce's fig. 10, Johnson et al.'s figs 11A-B, and D'Abrera's fig. "E. heodes ? \& R". It seems thus that someone switched the labels between the specimen from "Uramarca" and that from "San Marcas" as indicated by D'Abrera (1995: 1244). As shown by D'Abrera (1995), the specimen now labelled "San Marcas" ("San Marco" according to D'Abrera, who calls it "heodes of V") matches quite well Druce's fig. 11, though we wonder if that female is the same model used for Druce's fig. 11.

The species Strymon heodes can be easily separated from any other taxon included in Strymon by the following characters, which are unique in the genus.

1. Basal areas of dorsal wing-surfaces in both sexes covered by iridescent scales which reflect different colours (silver, golden, light blue) depending on angle of observation.

2. Antemarginal area of hindwing in both sexes without intercellular submarginal black spots but there are light blue scales at the end of cubital veins and the end of vannal vein 2 .

The characters listed are stable, only in the case of worn specimens it is difficult to detect, especially the light antemarginal scaling. According to these two characters all the synonyms placed under Strymon heodes by Robbins (2004) have to be removed and tentatively placed under $S$. bicolor, as had originally been proposed by Robbins \& Nicolay (2002). None of these taxa have the characters listed above but they show clear affinity to $S$. bicolor. Consequently the species level status proposed by Robbins (2004) is confirmed by us here by the following evidences: (1) S. heodes can be separated from all Strymon on the ground of wing characters and (2) $S$. heodes geographically is highly isolated from any other members of the $S$. bicolor species complex (cf. Figs. 10-11).

The most striking traits still are (1) the large male dorsal forewing scent pad (which can be easily detected also in the ventral wingsurface), (2) the orange scaling of the wing-surfaces with wide black margin in both sexes and (3) no basal white scaling on the ventral surface of the hindwing basal area. All the Strymon taxa which have these three traits were placed in the Strymon istapa group by Robbins \& Nicolay (2002). 

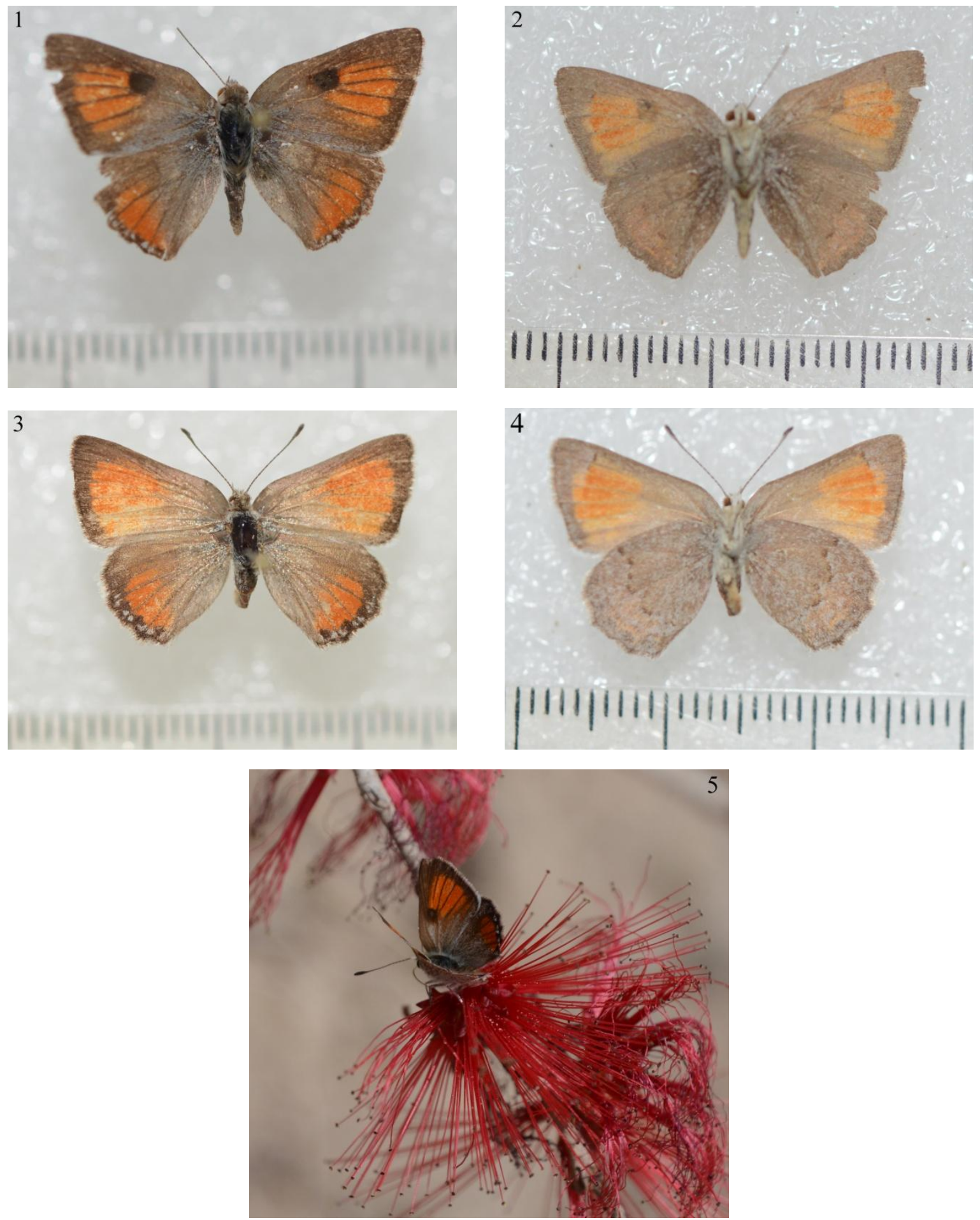

Figures 1-5. Strymon heodes (Druce, 1909) from Peru, Ancash, Caraz, 2400 m, 2002, leg. Weigend, MUSM: $1=$ male dorsal, 2 = male ventral, 3 = female dorsal, $4=$ female ventral; (scale: $1 \mathrm{~mm}$ ). The gleaming scales are well visible in the basal area of the wings in both sexes. $5=$ Fresh male of Strymon heodes (Druce) in nature perching on a red flower of Calliandra sp. (Mimosoideae, Fabaceae) in Peru, Department Ancash, Huaylas, at 2820m taken on 9.XII.2016. (photos: Dubi Benyamini). 
The genital structures of Strymon heodes are qualitatively identical to the species placed in the Strymon istapa group, namely the down-turned male aedeagus tip and the vesica containing a single slender cornutus, the female ductus seminalis arises from a point anterior to a sclerotized patch on the dorsal surface of the corpus bursae, and the 8th tergum is furrowed. Probably there are genitalia characters which could be used to discriminate quantitatively the taxa (see Johnson \& Miller 1992).

\section{Identity of Strymon bicolor}

(Figures 6-9, 11)

Lycaena? bicolor Philippi, 1859: 1092.

Thecla bicolor (Philippi): Hewitson 1877: 208, pl. 83, figs. 695-697; Butler 1881: 468; Elwes 1903: 289; Draudt 1920: 810, pl. 145, row k, figs. "bicolor".

Eiseliana bicolor (Philippi): Bridges 1988: II.33; Johnson et al. 1992: 115, figs. 2A-D, 4A-D, 9AC, 10A-C; D'Abrera 1995: 1244, 1245, figs. "E. bicolor"; Peña \& Ugarte 1997: 210 (figs. female and male).

Strymon bicolor (Philippi): Robbins \& Nicolay 2002: 99; Robbins 2004: 131.

The species $S$. bicolor can be easily separated from any other taxon belonging in Strymon by the unique combination of the following characters:

1. Male dorsal forewing with black scent pad in the apical area of the discal cell.

2. Basal area in both wing surfaces is black in both sexes.

3. Limbal area in both wing surfaces is orange in both sexes.

Beside Strymon heodes the only similar congeneric species is $S$. wagenknechti (Ureta), but in that species the basal and discal wing surface areas are orange, and the hindwing ventral surface median and submarginal areas are covered by white scaling, there is no orange colouration. The hindwing of $S$. wagenknechti is tailed.

\section{Distribution and synonyms of Strymon bicolor}

(Figure 11)

Lycaena? bicolor Philippi, 1859, type locality: Chile, „Le halla en las immediaciones de la Capital” [=
Santiago de Chile] (male and female syntypes, not extant).

Thecla quadrimaculata Hewitson, 1874, type locality: "Chili", ["Valparaiso"] (male and female syntypes).

Thecla bicolor f. leptocosma Hayward, 1949, type locality: Argentina, "Zapala, Neuquén" (male holotype).

Thecla bicolor ab. tricolor Ureta, 1949, type locality: Chile, "Las Trancas, Vicuña" (female holotype) (unavailable name).

Eiseliana probabila Johnson, Miller \& Herrera, 1992, type locality: "Valparaíso, Chile" (male holotype).

Heoda suprema Johnson, Miller \& Herrera, 1992, type locality: Argentina, "Chubut Prov., Esquel" (female holotype).

Heoda shapiroi Johnson, Miller \& Herrera, 1992, type locality: Chile, "Las Cruces, Cordillera Parral, Lináres [sic]" (female holotype).

Heoda atacama Johnson \& Miller, 1992, type locality: Chile, "Coquimbo, Elqui, C[ues]ta Pajunales [sic]" (male holotype).

According to Robbins \& Nicolay (2002) Strymon bicolor has many synonyms. Some of these names were proposed for distinctive populations living on the western or the eastern sides of the southern Andes, from the Atacama region to Patagonia.

According to our best knowledge the most northerly record of the species is a female specimen collected in Iquique, Chile by María Etcheverry Campaña in 1949 (deposited in SINMNH). But this is a unique specimen, and it can be a stray, or an accidentally introduced individual, or simply it has been mislabelled. The most northerly reliable data of S. bicolor is from Vallenar (Atacama, Chile) based on the personal observations of the junior author.

In the following paragraph we list all the names we place tentatively in synonymy with Strymon bicolor as they can be identified as such with the key we presented above. This list is identical with the synonymic list given for Strymon bicolor by Robbins \& Nicolay (2002) (except that we removed Thecla heodes from synonymy), but differs from the list of Robbins (2004) as we indicated in the Introduction. We are of the opinion that some of these names represent real 

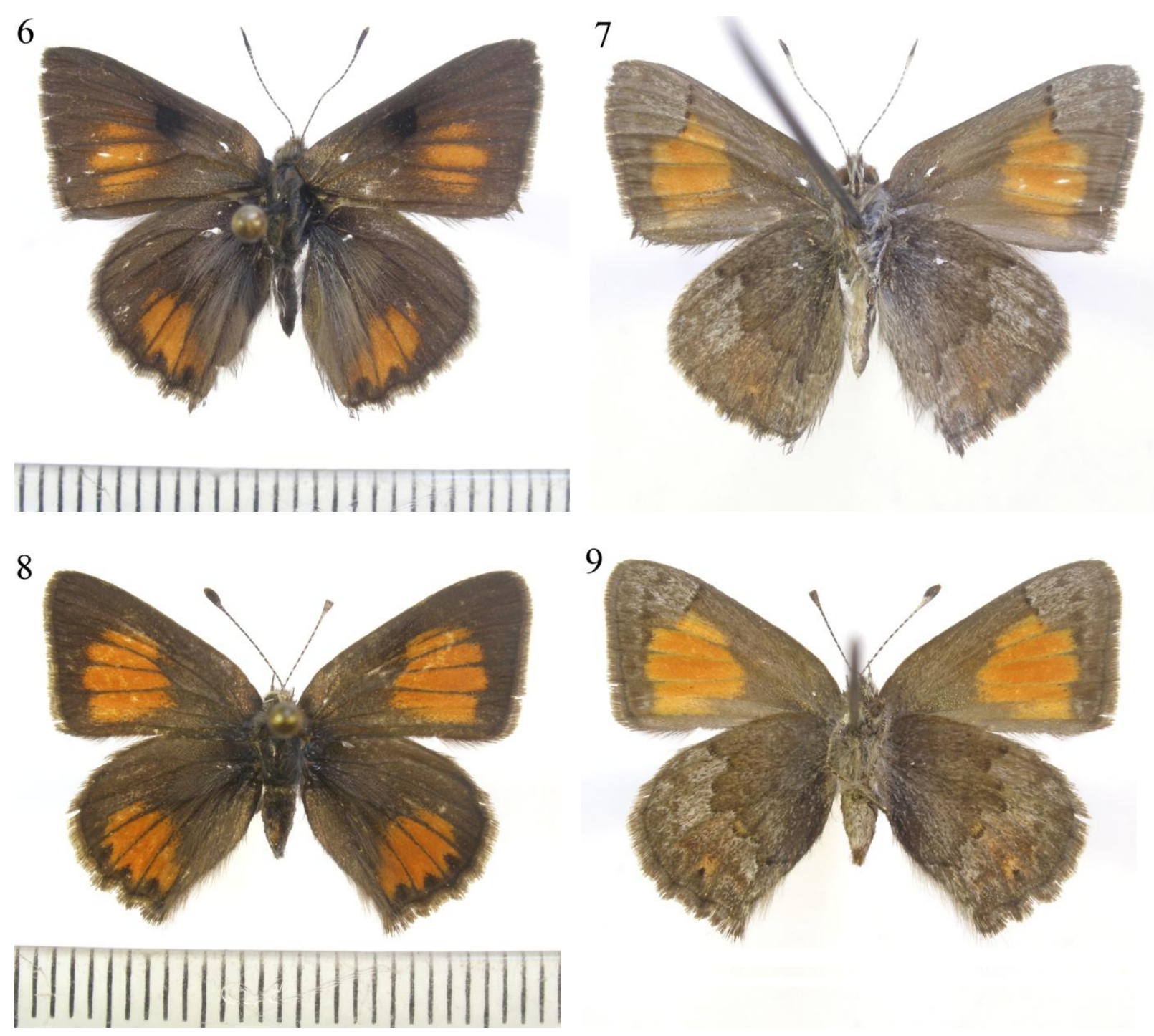

Figures 6-9. Strymon bicolor (Philippi, 1859) from Chile (Santiago, Villa Paulina, 2000 m, 1999, ex larva, leg. et coll. Dubi Benyamini, Bet Arye, Israel): $6=$ male dorsal, $7=$ male ventral, $8=$ female dorsal, $9=$ female ventral; (scale: $1 \mathrm{~mm}$ ) (photos: Gergely Katona, HNHM).

biological entities, therefore they deserve to be taxonomically recognized as species ( $c f$. Peña \& Ugarte 1997: 210-215).

\section{DISCUSSION}

\section{Problems with Strymon heodes historical material}

Johnson et al. (1992) mention one male from "Guarajunga, $2840 \mathrm{~m}$ [sic]", as well as another "male" from "Pampa Incas", and a third "male" from "Carohuas [= Carhuaz, Ancash], $2500 \mathrm{~m}$ " all three in NHMUK. In total, Johnson et al. (1992) mentioned having examined $4 \hat{\partial} \hat{0}$ and 3 우 of "Heoda heodes" as they indicate the existence of another female from "San Marcos", and another one from "Urumarca" in the collection. They provide illustrations of $\lambda$ and $q$ genitalia.

Beside documenting Thecla heodes type material, one specimen from "Guarapunga, $2450 \mathrm{~m}$ " 
has been illustrated by D'Abrera as "heodes $\widehat{O} \mathrm{R}$ " (but also given as $2480 \mathrm{~m}$ on p. 1258), which ought to be the same as Johnson et al.'s "male", but with different spelling and elevation of the locality. That specimen is definitely not a syntype, as it was not mentioned in the original description, and it is also not a male individual.

"Guarajunga" of Johnson et al. and "Guarapunga" of D' Abrera should be Huayrapongo, also in Cajamarca, at $07^{\circ} 11^{\prime} \mathrm{S}, 78^{\circ} 27^{\prime} \mathrm{W}, 2600 \mathrm{~m}$. The name "Pampa Incas" might refer to Baños del Inca $\left(07^{\circ} 10^{\prime} \mathrm{S}, 78^{\circ} 28^{\prime} \mathrm{W}, 2650 \mathrm{~m}\right)$, also in Cajamarca, another locality visited by Simons in November 1899 , or else La Pampa $\left(08^{\circ} 39^{\prime} \mathrm{S}, 77^{\circ}\right.$ $\left.54^{\prime} \mathrm{W}, 1800 \mathrm{~m}\right)$, in Ancash (cf. Lamas 1976).

Although it is written that "all Heoda species have forewing androconial brands in males" by Johnson et al. (1992: 121), they never mention this character in relation of their "Heoda heodes". It seems to be important to revise the seven NHMUK specimens and their labels, and compare them carefully with Druce's, Johnson et al.'s and D'Abrera's images in order to sex them properly, and if there are really any males of heodes among the NHMUK specimens examined by Johnson et al. (1992), and if the genital illustrations given in that paper (their figs. 14A-B) match actual specimens of heodes.]

\section{Mimicry ring}

In a review of the Chilean lycaenid butterfly life histories the junior author worked out a remarkable mimicry ring (Benyamini 1995). All the ring members have contrasting brownorange imaginal wing surfaces displaying apparently warning colouration and many of them utilize toxic plants as larval hosts. Without any question the species Strymon heodes belongs to this mimicry ring (see Benyamini 1995, fig. 11) and suggests that the biota exhibiting this phenomenon is also present in the Ancash-Cajamarca region in Peru. Consequently the mimicry ring has an almost continuous distribution from Patagonia via Chile-Argentina-Bolivia to Peru and most probably it takes an important ecological role in the dry areas of the Andes. This is underlined by the existence of further orange-brown lycaenid butterfly species as Penaincisalia aurulenta Johnson, 1990 also known from the Peruvian Ancash region, the hairstreak Penaicisalia felizitas Bálint, 2004 from the Cuzco region and by an undescribed Rhamma species recorded as "Strymon heodes" from the La Paz valley, Bolivia (see Guerra et al. 2013), plus Rhamma eiselei (Johnson, 1992) and Penaincisalia matusikorum (Johnson, 1992), both from Tucumán, Argentina.

\section{Generic placements}

Robbins \& Nicolay (2002) employed a wide concept for Strymon. They established nine species groups within the genus, and recognized 48 species, but later the number has been indicated as 55 (Robbins 2004) or 54 (Nicolay \& Robbins 2005). Strymon bicolor and $S$. heodes have been placed in the Strymon istapa group, characterized as follows: (1) male with a scent patch on the dorsal surface of the forewing; (2) no basal patch of white scales on the ventral surface of the hindwing; (3) aedeagus tip down-turned with a single slender cornutus; (4) ductus bursae with sclerotized loop simple; (5) ductus seminalis arises either from the unsclerotized posterior end of the corpus bursae or from a point anterior of a sclerotized patch on the dorsal surface of the corpus bursae; and (6) female with 8th tergum furrowed and with imbedded presumed vestigial spiracles. The last character was emphasized by the authors.

As the phylogenic relationships between the species of the Strymon istapa group are unresolved, there is no basis to apply the generic names Eiseliana and Heoda. The 


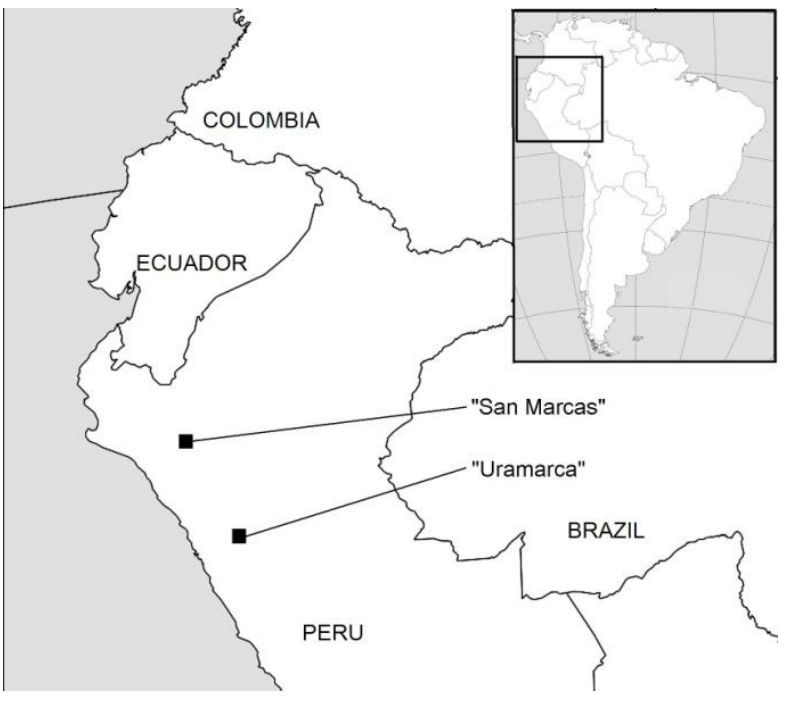

Figure 10. Localities of Thecla heodes Druce, 1909 syntype material; "Uramarca" = Yuracmarca, "San Marcas" = San Marcos (by Gergely Katona, HNHM).

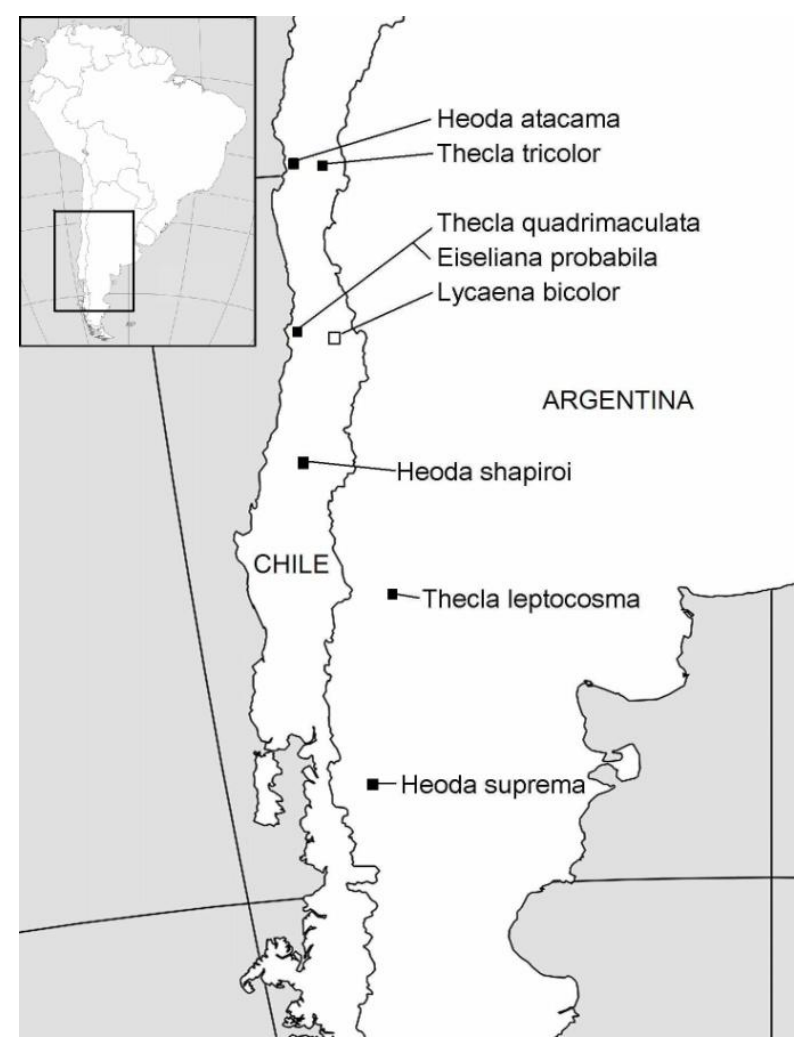

Figure 11. Type locality of Lycaena bicolor Philippi, 1859) (open square) and further nominal taxa placed currently under synonymy (black squares) indicating the general distribution of the group (by Gergely Katona, HNHM). generic name Eiseliana might be used for $S$. koehleri and its relatives, and Heoda for $S$. heodes and its relatives. The previous attempts of Johnson and his colleagues to construct several species groups within these genera were unsuccessful. This is especially apparent when we take into consideration that taxa obviously closely related have been placed either in Heoda or Eiseliana or Strymon. For example Thecla flavaria Ureta, 1956 has been placed in Eiseliana by Johnson et al. (1992: 114), but an apparently closely related species (or a synonym according to Robbins 2004), erani Benyamini \& Johnson, 1996, has been described in Heoda (see Benyamini \& Johnson 1996). Similarly, the nominal species Heoda atacama Johnson \& Miller, 1992 is surprisingly similar to Eiseliana bicolor, and its placements in different genera appears to be unjustified, as well as the case of the brown taxa Strymon peristictos Johnson, Eisele \& McPherson, 1990 (a synonym of Strymon eurytulus Hübner, [1819] according to Robbins 2004) and Heoda nivea Johnson, Miller \& Herrera, 1992. At our present knowledge of the genus Strymon the argument of Robbins \& Nicolay (2002) against the application of the generic names Heoda and Eiseliana seems to be justified, but the speciesgroup level synonyms they proposed for the Austral Strymon fauna in South America are in need of revision.

With this paper we make a first step and clarify the identity of Strymon heodes showing that although it is not a member of the Austral fauna, it is an endemic species of the Strymon bicolor group with restricted distribution in the Central Andes in Peru, but represents the same mimicry ring in which $S$. bicolor is also involved. However, we point to the situation that under the name of $S$. bicolor there are several species whose validity we trust to demonstrate by evidences in our forthcoming works. 
Acknowledgements - The authors express their sincere thanks to the following colleagues who let us study the collections under their care: Dr. Blanca Huertas and $\mathrm{Mr}$. Phillip Ackery (London, UK), Dr. Gerardo Lamas (Lima, Peru), Dr. Jacques Pierre (Paris, France), and Dr. Robert K. Robbins (Washington D.C., USA). Thanks are due to $\mathrm{Mr}$. Gergely Katona (Budapest, Hungary) and Mr. Ofir Tomer (Na'ale, Israel) for technical help and accompanying the junior author in the expedition made to document Strymon heodes in Peru. Finally we cordially thank (again) Dr. Lamas for improving our manuscript considerably via his review, and thanks also for an anonymous reviewer for the constructive remarks.

\section{REFERENCES}

AJMAT DE TOLEDO, Z.D. (1978): Fauna del NOA. Contribución al conocimiento de los Lepidópteros Argentinos VI. Eiseliana nuevo género de Lycaenidae (Theclinae, Strimonini [sic]). Acta Zoologica Lilloana, 33: 79-84.

BENYAMINI, D. \& Johnson, K. (1996): Review of Austral Heoda, with a new species from Chile (Lepidoptera: Lycaenidae: Eumaeini). Tropical Lepidoptera, 7: 13-20.

BenYAmini, D. (1995): Synopsis of Biological Studies of the Chilean Polyommatini (Lepidoptera, Lycaenidae). Reports of the Museum of Natural History, University of Wisconsin, Stevens Point, 52: 1-51.

BRIDGES, C. (1988): Catalogue of Lycaenidae \& Riodinidae (Lepidoptera: Rhopalocera). Illinois, Urbana: published by author, $788 \mathrm{pp}$.

BRIDGES, C. (1994): Catalogue of the family-group, genus-group, and species-group names of the Riodinidae \& Lycaenidae (Lepidoptera) of the World. Illinois, Urbana: published by the author, $1128 \mathrm{pp}$.

BUTLER, A.G. (1881): List of Butterflies collected in Chili by Thomas Edmonds, Esq. Transactions of the Entomological Society of London, 1881(4): 449-486. doi: 10.1111/j.1365-2311.1881.tb00876.x

D'ABRERA, B. (1995): Butterflies of the Neotropical Region. Part VII. Lycaenidae. Hill House, Victoria, p. i-xi, 1098-1270.

DRAUDT, M. (1919-1921): Familie: Lycaenidae, pp 744-831, pls. 144-159. In. Seitz A. (Ed.): Die Gross-Schmetterlinge der Erde. Alfred Kernen Verlag, Stuttgart, Volume 5.

DRUCE, H.H. (1909): On some new and little-known Neotropical Lycaenidae. Transactions of the Ento- mological Society of London, 1909(3): 431-438.

doi: $10.1111 / \mathrm{j} .1365-2311.1909 . t b 02177 . \mathrm{x}$

ELWES, H.J. (1903): The Butterflies of Chile. Transactions of the Entomological Society of London, 1903(3): 263-301. doi: $10.1111 /$ j.1365-2311.1903.tb01139.x

Guerra, J.F., Guerra, A.F. \& Guerra, Y.A. (2013): Mi guía de mariposas del Valle de La Paz. My butterfly guide of Valley of La Paz. Chuquiyaw qhirwa tuqin pilpintut yatxatawi. La Paz: Universidad Tecnológica Boliviana, $142 \mathrm{pp}$.

Hewitson, W.C. (1877): Illustrations of Diurnal Lepidoptera. Lycaenidae. London: John van Voorst, 1(7): 185-209 [sic], pls. 74-83.

JoHnson, K. \& MiLLER, L.D. (1992): Addition to the Chilean fauna. Reports of the Museum of Natural History, University of Wisconsin, Stevens Point, 23: 5-8.

Johnson, K., Miller, L.D. \& HerrerA, J. (1992): Eiseliana and Heoda, high Andean and Austral genera of the Neotropical Eumaeni (Lepidoptera: Lycaenidae). Acta Entomológica Chilena, 17: 107-146.

LAMAS, G. (1976): A gazetteer of Peruvian entomological stations (based on Lepidoptera). Revista peruana de Entomología 19(1): 17-25.

Nicolay, S.S. \& RobBins, R.K. (2005): Five new dryarea South American Strymon species (Lycaenidae: Theclinae) and their biogeographic significance. Journal of Research on the Lepidoptera, 38: 35-49.

PEÑA, L.E. \& UGARTE, A.J. (1997): Las Mariposas de Chile. The Butterflies of Chile. Santiago de Chile: Editorial Universitaria, 359 pp.

PHILIPPI, R.A. (1859): Descripción de algunas nuevas especies de mariposas chilenas, principalmente de la provincia de Valdivia. Anales de la Universidad de Chile, 16: 1088-1114.

RoBBINS, R.K. (2004): Introduction to the Checklist of Eumaeini (Lycaenidae). pp. xxiv-xxx; Tribe Eumaeini. pp. 118-137; Appendix: Lycaenidae: Eumaeini. pp. 275-282. In. LAMAS. G. (Ed.) Checklist of Neotropical Lepidoptera, Part 4A. Association for Tropical Lepidoptera and Scientific Publishers, Gainesville, xxxvi + 439 pp.

RobBins R. K. \& NiCOLAY S. S. (2002): An overview of Strymon Hübner (Lycaenidae: Theclinae: Eumaeini). Journal of the Lepidopterists' Society, 55: 85-100. 